\title{
Modiano historiador: a ambiguidade francesa durante a ocupação alemã compreendida na obra Ronda da noite
}

\author{
Modiano historian: the french ambiguity during the german \\ occupation included in La ronde de nuit
}

Thiago Tremonte de Lemos*

\begin{abstract}
Resumo: A partir da obra do escritor francês Patrick Modiano, o presente artigo propõe uma reflexão sobre os limites e os encontros entre a história e a ficção literária nas narrativas da ocupação alemã na França, durante a Segunda Guerra Mundial. Concomitantemente, discute-se a ambígua posição da sociedade francesa, particularmente em Paris, ora tolerando e, às vezes, colaborando com os invasores, ora resistindo à presença estrangeira.
\end{abstract}

Palavras-chave: Patrick Modiano; História; Literatura; França; Ocupação alemã; Segunda Guerra Mundial.

\begin{abstract}
This article proposes a reflection about the limits and meetings between history and literary fiction in the narrative of the German occupation of France, during World War II, in the french novelist's works, Patrick Modiano. Concurrently, discusses the ambiguous position of French society, particularly in Paris, or by tolerating and eventually collaborate with the invaders, sometimes for resisting foreign presence.
\end{abstract}

Keywords: Patrick Modiano; History; Literature; France; German occupation; Second World War.

* Ex-professor Adjunto da Universidade de Brasília, Brasília/DF, Brasil.. E-mail: tremontethiago@hotmail.com

(c) EY Direito autoral e licença de uso: Este artigo está licenciado sob uma Licença Creative Commons. Com essa licença você pode compartilhar, adaptar, para qualquer fim, desde que atribua a autoria da obra, forneça um link para a licença, e indicar se foram feitas alterações. 
Você tinha razão de me dizer que na vida não é o futuro que conta, é o passado ${ }^{1}$

Eu sou um produto da Ocupação, de uma época em que se encontravam em um mesmo lugar um traficante do mercado negro, um membro da Gestapo da rua Lauriston e um homem procurado. Nesse cenário, meu pai, um judeu cosmopolita, encontra-se com minha mãe, de origem flamenga, atriz de cinema antes da guerra ${ }^{2}$

\section{Introdução}

Em junho de 1940, Paris foi ocupada pelas tropas alemãs, que ali permaneceram até 1944. Além do triste significado político e militar, a invasão representa uma situação incômoda para a história francesa: de um lado, se nota a resistência ao intruso e, de outro, não se esquece da colaboração com ele. Para alguns, a rotina não mudou muito e, após alguns dias "a vida retomou quase o mesmo curso anterior". ${ }^{3}$ Para outros, principalmente os parisienses judeus, nada seria como antes, sobretudo após a instalação da Gestapo no número 84 da avenida Foch. ${ }^{4}$ Para alguém como o escritor francês Patrick Modiano, que nasceu em 1945, filho de judeu, a Paris ocupada significou, antes de mais nada, um encontro com suas origens, com sua "paisagem natural", segundo as palavras de Norma Ribelles Hellín ${ }^{5}$, da Universidad Miguel Hernández.

A percepção de Modiano sobre a história da França ocupada (detectada em muitos de seus livros) é tocante não apenas por poder reconstruí-la com a desenvoltura e a argúcia de um investigador policial, mas por narrá-la tal como um historiador, além de inventar enredos ambientados em um tempo de sombras. Há também o fato do autor se perguntar o que faria caso tivesse nascido antes. Em sua primeira obra, La place de l'étoile, "Raphaël Schlemilovitch, o narrador (...) é, de uma vez e sucessivamente, judeu e colaborador, cafetão e perseguido, antissemita e amante de Eva Braun". ${ }^{6}$ A ambiguidade é a marca indelével das principais personagens de Modiano, uma vez que se perdeu a identidade francesa da geração da ocupação.

A principal razão de ser da história é não deixar esquecer. Em algumas histórias, propositadamente, esquecem-se de alguns acontecimentos. Em outras, exageram-se certas lembranças. Isso sem falar da importância dada a essa ou aquela perspectiva, a esse ou aquele método de análise, de construção da narrativa e das suas implicações políticas. Sobretudo, escrever a história é fazer presente algo que nem sempre é recuperável pelo exercício 
da memória. Caberia, portanto, ao historiador, em seu ofício, não somente realizar o propósito da história como denunciar toda e qualquer tentativa de sua falsificação, manipulação etc. Logo, é de se supor o que é e o que não pode ser o dever da história.

Ao longo da história contemporânea, o sério debate sobre os limites da história, como se sabe, não foi matéria restrita aos historiadores. Não cabe, contudo, enumerar os partícipes da querela, que ora procurou retirar o privilégio desse saber da alçada exclusiva dos iniciados historiadores, ora reforçou a necessidade de uma ciência específica para o mesmo saber.

Acredita-se aqui que as críticas mais contundentes à escrita da história provêm de pensadores que são historiadores, de formação ou por direito, o que não legitima, por princípio, qualquer posição em si e nem desautoriza opiniões contrárias. O que ocorre, em certos casos, é a sucessiva necessidade de se retornar ao encontro da narrativa ficcional com a história científica propriamente dita, como momento e lugar do que surge como interstício. Citam-se, por exemplo, duas obras-primas da literatura ocidental do século XIX: Os miseráveis, de Victor Hugo, e Guerra e paz, de Tolstói. Ambas ficcionais. Ambas enredadas em contextos históricos imaginativamente descritos e, apesar de alguns equívocos insignificantes (nomes de pessoas, lugares, algumas datas etc.), com razoável rigor representados. O trecho sobre a batalha de Waterloo, de Hugo, talvez, seja a mais clara expressão do evento. Na batalha de Austerlitz (poderiam ser mencionadas outras) descrita por Tolstói, não apenas há uma dimensão do que foi o evento em si, mas a "realidade" dos fatos se mistura intrinsecamente aos desdobramentos do romance. Tanto em uma obra como em outra, a discussão sobre a história e a imaginação estava posta. Tolstói escreveu uma profunda reflexão sobre a história, sua narrativa e a humanidade de uma forma geral no início do segundo volume e no epílogo de seu livro. ${ }^{7}$ Hugo, por sua vez, tratou com astúcia a importância daquela passagem de sua grande obra, abordando o valor histórico em si da batalha de 1815, bem como seu legado e seu significado para o século XIX.$^{8}$ Os dois livros, lembra-se, foram publicados na década de 1860 e parecem representar, com algum exagero, o espírito de todo o oitocentos.

Se por um lado, há a exigência do que Carlo Ginzburg nomeou de "princípio de realidade", ou seja, "qualquer documento, a despeito de seu caráter mais ou menos direto, sempre guarda uma relação altamente problemática com a realidade, mas a realidade ('a coisa em si') existe"; 9 por outro, como não perder de vista a contribuição para o entendimento do espírito de uma época que o próprio Ginzburg salientou ao destacar a importância da obra de Stendhal, particularmente $O$ vermelho e o negro, sobre o século XIX?

$O$ vermelho e o negro era uma representação pontual da sociedade francesa sob a Restauração. Pontual, sem dúvida nenhuma: mas as características descritas eram destinadas a 
se prolongarem muito além da sua localização original, como Stendhal sugeriu indiretamente num dos dois subtítulos de $O$ vermelho e o negro: 'Crônica do século XIX'. Numa nota de rodapé posta no fim do romance, que à primeira vista pretendia assinalar o valor puramente arbitrário dos lugares em que ele se desenrola (...), Stendhal acenou para as implicações históricas mais gerais da história por ele contada: 'Nos países em que reina a opinião pública, o que de resto proporciona a liberdade, tem-se o inconveniente de que ela se imiscui até no que não lhe diz respeito: por exemplo, na vida privada. Daí a tristeza da América e da Inglaterra (...). Com o uso de termos como 'opinião' e 'liberdade', que evocam a atmosfera política da Revolução de 1830, Stendhal indicou a importância do romance para a França do episódio posterior à Restauração. A referência à Inglaterra e à América era igualmente eloquente. Para Stendhal, os dois países simbolizavam o futuro: um futuro tétrico, em que todas as paixões desapareceriam, salvo uma, a paixão pelo dinheiro. Tédio e tristeza, produzidos pela intrusão da moralidade na vida privada, eram as características das sociedades industriais modernas, dentre as quais podia ser arrolada a França. ${ }^{10}$

Afinal, a ficção é mais pertinente para lembrar o século XIX do que todo o esforço que a historiografia empenhou nesse assunto? Ou seria um documento mais fidedigno à realidade daquela época, daquele lugar, do que qualquer outro escrito descritivo dos fatos vivenciados? Talvez seja inútil, aqui, elucubrar uma hipótese satisfatória (ainda que provisória). Seria melhor, portanto, encontrar expressões narrativas que se encaixem ao debate, mesmo que imprecisamente, e ofereçam imagens mais ou menos representativas da história, da memória e do esquecimento.

A obra de Patrick Modiano é uma importante contribuição desse tipo de representação estética da realidade social do século XX. A despeito da predicação, que é absolutamente um juízo de valor desprovido de outra razão que não o gosto, Modiano não pode ser considerado um historiador. No entanto, é assim que será tratado na presente reflexão.

Nesse sentido, cabe salientar àqueles que conhecem o trabalho de Richard Golsan ${ }^{11}$ que o título deste texto não é apenas uma inspiração, mas uma cópia do nome do artigo de Golsan. As aproximações entre os textos, todavia, não vão muito além disso. Ainda que existam pontos em comum, uma vez que 
o objeto de análise de Golsan é a obra Dora Bruder (1997) e o deste é Ronda da noite (1969) - ambas de Patrick Modiano, evidentemente -, as conclusões alcançadas aqui diferem em razão do método (e também do estilo) adotado por Modiano nas duas obras. ${ }^{12}$ No artigo de Golsan, o foco é a deportação de judeus franceses e a história (ou micro-história) narrada por Modiano a partir de sua investigação sobre o que aconteceu com Dora Bruder - uma garota judia de 14 anos, procurada por seus pais -, instigada pelo contato do autor, em 1988, com um recorte de jornal de dezembro de 1941, no qual a família Bruder anunciava o desaparecimento da adolescente. Modiano se empenhou em uma pesquisa de oito anos até o término do livro. Entre tantos detalhes que emocionam em sua escrita, apresentando ao longo do romance todo seu esforço como um detetive atrás de rastros, não totalmente apagados, mas com lacunas e ausências sensíveis, está o desfecho de sua obra sobre o tesouro inviolável da história humana, restrito ao indivíduo, no caso, Dora. ${ }^{13}$

Assim, se o escopo deste artigo se restringisse a Dora Bruder, seria preferível manter-se com a leitura do texto de Golsan (mais erudito e bem escrito). No entanto, uma vez que aqui se deseja problematizar a contemporaneidade, a partir de sua complexa e insolúvel busca pela objetividade da escrituração historiográfica, optou-se pela análise do romance Ronda da noite, em razão da natureza ambígua do escrito, ora ficção, ora história.

Afirma-se, desse modo, o seguinte propósito: a memória e, por conseguinte, uma boa história do século XX, em particular da Segunda Guerra Mundial, especialmente sobre a cidade de Paris ocupada pelos alemães, não foi escrita por alguém que esteve ali presente, nem por algum historiador que tenha pesquisado incansavelmente. Modiano representou os acontecimentos vivenciados de forma mais sensível que qualquer outro e com algum cuidado. Logo, a análise acadêmica não se faz apenas dos documentos produzidos, das crônicas escritas e dos vestígios legados, faz-se também e sobretudo de suas representações.

Retomando-se a razão da escolha do título do presente artigo, novamente, aborda-se o texto de Golsan e os propósitos desta reflexão. Se em Dora Bruder a narrativa mistura o encadeamento, de um modo possível, dos acontecimentos históricos com elementos da biografia do autor e de seu pai - não havendo, aparentemente, tantos espaços para a ficção -, o que se vê em Ronda da noite é exatamente o oposto: partindo-se de um cenário verossímil, com algumas personagens criadas pela inspiração em homens reais, o que está em jogo não é apenas a história de um ou de alguns franceses, é a crise de identidade da própria França. Pode-se inferir que o momento difícil da história francesa foi resultado tanto da fragorosa derrota nos campos de batalha quanto da triste "aceitação" de setores civis e militares acerca da dominação alemã.

É fato que o campo de Drancy e o Vélodrome d'hiver são lembranças vergonhosas da tenebrosa história da ocupação. Por outro lado (ou por diferentes 
vertentes políticas e acadêmicas), cabe-se perguntar se as dúvidas que pairam sobre a colaboração ou não dos franceses são efetivamente dúvidas e se a indagação, por isso mesmo, não teria valor senão retórico ou se é exatamente o estado de torpor diante dos horrores vivenciados na Segunda Guerra Mundial, não apenas no leste europeu - principal cenário dos campos de extermínio, em especial a Polônia - mas no ocidente da Europa, particularmente na França, que, na impossibilidade de concretamente se opor ao regime nazista, paralisou qualquer ação pró ou contra a ocupação.

Para Pascal Ory ${ }^{14}$, o colaboracionismo francês não foi uma fatalidade. Entretanto, não se deve atribuir a aspectos singulares sua existência. Fatores como o crescimento do fascismo, a bipolarização política da França em esquerda e direita, o antissemitismo, setores germanófilos e também a atração de camadas "marginalizadas" podem ser compreendidos em conjunto para interpretação do surgimento dos colaboradores franceses. Sobretudo, uma possível ênfase ao último ponto. A explicação simplória de que os "gângsteres" franceses puderam, com a Gestapo, agir livremente, eliminaria os outros componentes das causas da colaboração, ainda que, no caso específico da obra de Modiano, sirva para intensificar os elementos críticos do escritor sobre a conduta de certas personagens.

Para Dan Franck, no que se refere à atuação de artistas e intelectuais, houve de fato uma divisão entre os franceses, como se fosse um reflexo de toda a sociedade parisiense, que, todavia, deixava um grande espaço sem forma, sem conteúdo...

De um lado, havia aqueles que sofriam e não aceitavam. De outro, aqueles que sofriam e aceitavam. Havia também aqueles que aceitavam sem sofrer, como a minoria de pétanistas, doriotistas, hitleristas, que prestariam contas cinco anos mais tarde. E aqueles, em grande número, que decidiram 'se acomodar', aceitando se mover na pequena área concedida pelo invasor. Nem de todo desprezíveis, nem heroicos, de modo algum. Em todo caso, expondo, publicando, se apresentando, fechando os olhos para as misérias e as tragédias dos vizinhos. ${ }^{15}$

Hannah Arendt faz lembrar que os regimes totalitários - no caso o nacional-socialista - produzem e reproduzem de tal modo o mal, a ponto de banalizá-lo, que, pouco importando o grau de engajamento voluntário individual, todos (todos mesmos, não apenas carrascos e vítimas) atuam de uma forma ou de outra na realização do horror.

Compreende-se aqui, para tanto, que toda e qualquer reflexão, amparada ou não nos fatos reais, fundamentada ou não na análise da documentação disponível, não poderá jamais responder categoricamente qual 
foi o nível e a adesão à colaboração dos franceses com o nazismo (voluntária, involuntária, coagida, por omissão ou, simplesmente, por ignorância) ou, ainda, se os franceses resistentes se sentiram de fato obrigados a assumir um lado claro e combativo no período entre 1940 e 1944. Com isso, porém, não se deseja de outro modo afirmar que havia indiferença, subserviência ou simplesmente aceitação francesa ao domínio alemão. Não obstante apenas uma pequena minoria tenha se posicionado abertamente (ou tacitamente) favorável à presença invasora, não seria o caso de se excluir a vergonha, a ambiguidade e, por que não inferir, a negligência francesa durante a fase da ocupação. Talvez sim, talvez não... Haveria, entretanto, uma única certeza: a incapacidade de se decidir seguramente pelo papel desempenhado pela sociedade francesa durante aquele momento. Ora, se é exatamente o paradoxo o que resta de substancial, não seria a historiografia engajada tanto em acusar os colaboracionistas quanto em promover o esforço da Resistência, mesmo cuidadosa em apontar as exceções - de um lado ou de outro -, a melhor maneira de se capturar o espírito daquela história? Quiçá a ficção - mas apoiada no que Carlo Ginzburg chamou de "princípio de realidade" - possa não resolver o paradoxo, ao contrário, possa apontar diretamente para a impossibilidade de qualquer solução e, concomitantemente, desnudá-lo em sua natureza inalcançável.

Ronda da noite (La Ronde de nuit) é o segundo livro de Modiano. Insere-se no que se convencionou chamar de sua primeira trilogia da ocupação (La Place de l'Étoile, de 1968, e Les Boulevards de Ceinture, de 1972). ${ }^{16} \mathrm{O}$ enredo, centrado no protagonista-narrador sem nome (Princesa de Lamballe ${ }^{17}$ ou Swing Troubadour, um agente duplo, que atuava tanto na Resistência, quanto na Gestapo Francesa), é uma síntese possível do que se passava na França entre 1940 e 1944: um país dividido, não somente em termos geográficos, duplo, esquizofrênico, ambíguo etc. Do lado da Gestapo, mais do que tipos "verossímeis", são identificados imediatamente como pessoas moralmente reprováveis. Além disso, Modiano caracterizou duas dessas personagens a partir de sujeitos reais da verdadeira instituição: "Henri Normand, apelidado 'o Khédive' (por causa dos cigarros que fumava), era um velho condenado pela Justiça. Pierre Philibert, um inspetor-chefe exonerado. Dei-me conta de que me encarregavam de tarefas 'pouco conforme à moral'". ${ }^{18}$ Henri Normand foi inspirado em Henri Lafont (1902-1944), chefe da Gestapo francesa, e Pierre Philibert, em Pierre Bonny (1895-1944), outro colaborador da polícia secreta nazista na França ${ }^{19}$. Além disso, o bureau da rua Cimarosa, $\mathrm{n}^{\mathrm{o}} 3$ bis, também se baseou naquele utilizado por Lafont e Bonny, na rua Lauriston, $\mathrm{n}^{\mathrm{o}}$ 93, onde os prisioneiros eram levados ao subsolo e torturados muitas vezes (assim como descrito em algumas passagens do livro).

Henri Louis Chamberlain, ou Henri "Lafont", comandava um grupo razoavelmente complexo na perseguição aos membros da resistência francesa. 
Havia cinco seções com trinta pessoas, submetidas às ordens de homens de confiança de Lafont. Consequentemente, ampliando-se em uma rede de colaboradores indiretos (informantes ocasionais, por exemplo), havia um pouco de confusão administrativa entre os quadros da Gestapo Francesa. O número total de agentes franceses no serviço policial, entre 1940 e 1945, é evidentemente difícil de se conhecer com precisão. Contudo, a estimativa de trinta mil gestapistes diretos ou indiretos, não parece tão absurda após uma primeira avaliação, segundo Ory. ${ }^{20}$

Pierre Bonny, após quase duas décadas de atuação policial na França, marcada por processos administrativos, suspensões e julgamentos sobre a sua conduta, entre o fim de 1941 e o início de 1942, encontra, por acaso em um café de Paris, um antigo conhecido de nome Jean Aimé Guélin. Este falava da criação de uma agência que precisava de homens com o seu perfil. Bonny recebeu um pequeno pedaço de papel com as seguintes coordenadas "Henri Lafont, 93, rue Lauriston". ${ }^{21}$ Os agentes da rua Lauriston, 93, particularmente Lafont e Bonny, tinham documentos que mencionavam em francês e em alemão que o seu portador pertencia ao serviço secreto alemão e podia circular livremente, evitando assim, ter de prestar contas às autoridades francesas e alemãs. ${ }^{22} \mathrm{Os}$ crimes perpetrados por Lafont e Bonny, contudo, não são conhecidos com exatidão e nem quantos foram ao todo por uma razão muito simples: os arquivos da agência foram ou destruídos, ou simplesmente desapareceram. ${ }^{23}$ Após a libertação da França, os colaboracionistas foram perseguidos. Entre agosto e setembro de 1944, Bonny e Lafont foram presos e interrogados. Nos primeiros dias de dezembro, realizou-se o julgamento "da Gestapo francesa da rua Lauriston", como ficou conhecido o processo. Eles e outros seis agentes foram condenados à morte. A execução ocorreu no dia 27 de dezembro. ${ }^{24}$

Já o personagem-narrador de Modiano encara, mais com vontade do que certeza, o destino ambíguo de ser francês na Paris ocupada. Em certo trecho do início do livro, descreve em tom "veemente" sua decisão traiçoeira.

Desde minha infância, prometi tantas coisas que não cumpri, marquei tantos encontros aos quais não fui, que me parecia 'coisa de criança' tornar-me um traidor exemplar. 'Esperem, já volto (...)'. Todos esses rostos contemplados uma última vez antes que a noite os engolisse (...). Alguns não podiam nem imaginar que os abandonava. Outros me encaravam com olhos vazios: 'Escuta, você vai voltar?' Lembro-me também dessas curiosas pontadas no coração a cada vez que olhava meu relógio (...). Ainda não perderam a confiança. Tinha vontade de correr até o lugar de encontro e a vertigem, em geral, durava uma hora. Denunciar é muito mais fácil (...). Alcaguete. Tornar-me-ia assassino até, se eles quisessem. Abateria minhas vítimas com um silenciador. ${ }^{25}$ 
Mais adiante, a dúvida. Esta, quem sabe, mais contundente que a vontade de ser traidor. Talvez, também, porque colaborar com o inimigo não fosse necessariamente o mais odioso na relação que se estabeleceu entre franceses e alemães (ou com franceses que se submeteram "voluntariamente" à presença alemã), mas encontrar quem lutasse contra tal intrusão o fazia sentir, de uma forma fraterna, apunhalar este que deseja sua própria liberdade.

Eles irão ser presos daqui a pouco. Dir-se-ia que pedem um acerto de contas. Durante alguns minutos, não há arrependimento nenhum por ter-se entregado os endereços. Diante destes heróis que perscrutam com seu olhar claro, fica-se tentado a gritar bem alto a sua qualidade de delator (...). Uma lágrima escorre na face de um deles. Um outro reclina a cabeça e olha você tristemente. Um outro encara você com estupor, como se ele não esperasse isto de sua parte (...). O REMORSO. Estes rostos nunca mais deixarão de girar e, doravante, você dormirá mal. Mas uma frase do tenente ${ }^{26}$ volta à sua memória: 'Os caras da minha organização são duros na queda. Morrerão se for preciso, sem abrir o bico'. Então, muito bem. Novamente seus rostos se endurecem. Os olhos azul-escuros do tenente. Dez, vinte outros olhares carregados de desprezo. Já que querem morrer em estado de graça, que morram! ${ }^{27}$

De um lado o orgulho nacional maculado, o amor próprio em xeque, a soberania abalada pela submissão à Alemanha, após a derrota militar. De outro, alguma tolerância à presença estrangeira - por mais que houvesse uma significativa resistência - e, por que não dizer, certa afinidade ideológica de segmentos sociais franceses com os valores nazistas. ${ }^{28}$ Basta lembrar o que escreveu Hannah Arendt, em Origens do totalitarismo, sobre o antissemitismo francês, organizado politicamente antes mesmo do antissemitismo alemão, e sobre o caso Dreyfus, como exemplo de um episódio no mínimo constrangedor para a sociedade francesa, ainda no século XIX.

Enquanto o Caso Dreyfus em seu amplo aspecto político pertenceu ao século XX, o processo Dreyfus e os vários julgamentos do capitão judeu Alfred Dreyfus são bem típicos do século XIX (...). As dramatis personal do processo pareciam ter saído das páginas de Balzac: de um lado, os generais classistas procurando freneticamente acobertar os membros de seu próprio grupo e, de outro, o antagonista deles, Picquard, com sua honestidade calma, clarividente e levemente irônica (...). Tudo isso pertence tipicamente ao século XIX e, por si mesmo, jamais 
teria sobrevivido a duas guerras mundiais (...); em suas implicações políticas, pôde sobreviver porque dois de seus elementos cresceram em importância no século XX. O primeiro foi o ódio aos judeus; o segundo, a desconfiança geral para com a república, o Parlamento e a máquina do Estado (...). Ainda em nossos dias, o termo antidreyfusard pode definir a França, de modo aceitável, tudo o que é antirepublicano, antidemocrático e anti-semita. ${ }^{29}$

Tem relevância não somente o caso em si, que já era fraude, mas como a sociedade francesa se dividira após o evento em "dreyfusistas" e "antidreyfusistas", como tão bem ilustrou, denunciou e criticou Marcel Proust na obra Em busca do tempo perdido, sobretudo no terceiro livro, O caminho de Guermantes. ${ }^{30}$ Além do antissemitismo francês pré-guerra, havia também setores no país, sobretudo durante os anos 1930, considerados "germanófilos", ou seja, que defendiam a aproximação entre França e Alemanha, como matriz de uma futura Europa unificada. ${ }^{31}$ Bem como segmentos simpatizantes do fascismo - entre eles a Action française - que se admiravam ideologicamente os regimes alemão e italiano e atuavam em redes internacionais de solidariedade a outros grupos no combate ao comunismo. Dois exemplos ilustram essa afirmação: o apoio ao governo italiano na guerra da Etiópia (de intelectuais entusiastas do imperialismo ocidental) e às tropas franquistas na Guerra Civil Espanhola. ${ }^{32}$

À dupla personalidade encarnada no personagem-narrador de Modiano, agregam-se aquelas figuras pusilânimes e repugnantes que buscam tirar qualquer vantagem, mesmo que vendendo a alma ao carrasco de seu país, e os utópicos heróis que lutam tragicamente pela reconquista de sua dignidade. O agente duplo de Modiano não é apenas um sujeito que transita entre os dois lados do conflito: ele é as duas coisas, pusilânime e herói! 'E eu? Quem teria podido prever que me tornaria cúmplice de um bando de torturadores? Mas bastava acender a luz e descer até o salão para que as coisas retomassem seu aspecto anódino". 33

Suas dúvidas, autocríticas e atitudes são resultado dessa ambiguidade, ou melhor, dessa cumplicidade demasiadamente humana com as fraquezas e virtudes que afetam a todos. Entretanto, Modiano não está se referindo à espécie humana. Ele fala do francês. Não só o que ele era - ou o que achava que era talvez -, mas da história de uma França que não poderia ser mais a mesma depois de tal experiência. Como Stendhal em $O$ vermelho e o negro (guardadas as devidas proporções), na análise de Carlo Ginzburg, Modiano lança um terrível desafio aos historiadores: como capturar efetivamente o que aconteceu e não apenas os fatos inertes? Não seria de se perguntar também se não é somente o trabalho de um ficcionista que realiza essa tarefa?

Tomando como ponto de partida a obra Mimesis, de Erich Auerbach, sobre a representação da realidade na literatura ocidental, Ginzburg, com certa 
dose de pirronismo, introduz a problemática de Stendhal de forma muito clara: poderia haver outra obra que representasse tão bem o que foi o século XIX francês como o fez $O$ vermelho e o negro? Jamais por acaso, Ginzburg se lembra do subtítulo do livro: "Uma crônica do século XIX". Ainda que a obra tenha sido publicada na primeira metade do século XIX, em 1831, Stendhal - e Ginzburg está de acordo - entendia que não apenas em 1830 a França encerrava uma época de sua história como iniciaria outra, caracterizando, por assim dizer, todo o século XIX. A “captura” do espírito de uma época seria, portanto, tarefa dos romancistas e não dos historiadores. O rigor da ciência histórica impede que se alcance tamanho nível de compreensão. Agora, o que marca mais a identidade do passado senão a ficção que se faz dele? Foge-se dos eventos realmente registrados, é fato, mas se desses só é possível aproximar-se de um modo (ou mesmo alguns) pelo rigor científico, por que não desfrutar de uma visão mais geral, por assim dizer?

Isso não impede, no entanto, ressaltar que mesmo de outro modo, o escritor pode, com cuidado investigativo, atingir mais com perguntas do que respostas o mesmo efeito sensível, criando não apenas reflexões sobre o que aconteceu (e também sobre o que não aconteceu), mas sobre aquilo que nunca pode ser respondido. Atuando nos meandros do real e do fictício, a veracidade da história ressurge com força, como algo que recoloca a vivacidade do que passou, sem o intuito de revivê-lo, todavia, com a intenção de senti-lo à distância, mesmo para aqueles que não têm a memória como aliada nesses casos, como se dá com Modiano. Nascido em 1945, o autor não pode sequer afirmar que "era assim que nos sentíamos durante os dias da ocupação". Mas o faz por responsabilidade e herança. Inconscientemente, não deve haver francês que não sinta uma ponta de vergonha em relação à história da ocupação nazista.

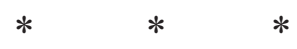

O que faz Patrick Modiano historiador, como intitula, em artigo de 2007, o professor da Texas A\&M University Richard J. Golsan? O francês, laureado com o prêmio Nobel de Literatura em 2014, popular em seu país, é filho de pais que se conheceram na Paris ocupada pelos nazistas e esse é o cenário de muitos de seus romances. Contudo, como seria possível afirmar que o escritor seria um historiador, tendo em vista que suas obras não são propriamente caracterizadas pela pesquisa documental rigorosa ou mesmo tenham como pressuposto a descrição fidedigna de eventos acontecidos? Certamente, Golsan responde à questão em seu artigo.

Norma Ribelles Hellín ${ }^{34}$, por sua vez, é contundente ao negar a Modiano a condição de historiador. De acordo com a autora, ao se apoiar na ideia de Milan Kundera - de que o romancista não seria historiador ou profeta, mas um explorador da existência -, Modiano não teria por objetivo descrever a 
realidade dos acontecimentos, tampouco seu significado histórico e político. Tanto seria assim que o escritor não recorreu a obras da historiografia para auxiliá-lo. Finalmente, para ela, a ocupação de Paris pelos alemães, nos escritos de Modiano, não seria histórica, mas imaginada, sonhada. "Narra sua história como um sonâmbulo contaria seu passeio noturno". ${ }^{35}$ Todavia, tomando a liberdade de utilizar seu artigo "La atmósfera de la ocupación alemana en las novelas de Patrick Modiano", no que se segue após essa negação e também na argumentação apresentada, chega-se aqui a uma opinião diametralmente oposta: Modiano é historiador. ${ }^{36}$

Para Modiano, a França era antissemita e, portanto, simpática ao nacional-socialismo. O antissemitismo, como mencionado, não era inédito no solo francês antes da presença alemã, mas com a ocupação, tornou-se mais explícito e intenso: com a dominação estrangeira, o francês precisava mostrarse forte e de alguém para descarregar todo seu ressentimento. "Se o judeu não existisse, seria inventado". Modiano não se atém, em nenhum momento, a teorizar sobre o judaísmo, porém muitas personagens se caracterizam pela capacidade de sobreviver às perseguições. Para isso, optam por vidas duplas, triplas etc. Enfim, ao fazer a crítica ao antissemitismo francês, apropria-se de uma de suas principais razões (o fato de o judeu ser antes judeu que francês), invertendo seu valor: na França ocupada, o verdadeiro rebelde, talvez o "francês real", é aquele que se torna apátrida, sem identidade (ou com muitas) e que não se deixa dominar, seja pelo "francês da resistência", seja pelo alemão invasor. O judeu é a melhor representação do estrangeiro em seu próprio país. Tal reflexão poderia ser vista por interpretações mais ortodoxas como uma posição, até certo ponto, "antissemita" (certamente negada por Modiano). Todavia, a discussão sobre o judaísmo, especialmente no contexto do genocídio dos judeus durante a Segunda Guerra Mundial, em geral, tem alguns contendores que veem as coisas e a história por um binóculo bastante enferrujado (basta lembrar o que passou Hannah Arendt quando da cobertura do julgamento de Eichamnn, belamente abordado por Margarethe von Trotta em um de seus filmes).

Modiano é tratado como um escritor indiferente ao debate político (o que não parece), uma vez que sua prosa não manifesta posições explícitas. Mesmo o tema da Shoah não ganha os tons fortes que se espera de quem trata da perseguição sofrida pelos judeus. No entanto, é exatamente essa sensação de silêncio, daquilo que não é possível ser narrado que dá a dimensão histórica mais forte de seu texto. Aqui, um trecho de Hellín é precioso exatamente para confirmar que Modiano - aparentemente indolente com a história, com a política, com o genocídio etc. - é, por certo, um autor que encontrou precisamente a melhor maneira de representá-los.

Modiano claramente demonstra que prefere o pudor à raiva. Assim, o olhar frio e distante das personagens (...) denuncia a indiferença frente a guerra e aos sofrimentos. Em 
seus romances (...), ninguém se altera ou se indigna. Este silêncio representa o silêncio dos campos de concentração. Frente aos criminosos, os protagonistas permanecem mudos. Porém, a falta de denúncia constitui em uma denúncia de outro tipo: afirma a banalidade do mal, deixando ao leitor a porta aberta para as suas próprias deduções. ${ }^{37}$

Como se sabe sobre Modiano, ele acompanhou de perto as consequências sofridas por aqueles que estiveram envolvidos com a ocupação nazista da França durante a Segunda Guerra Mundial. Contudo, apesar de não se preocupar apenas em contar narrativas que tiveram o panorama histórico da ocupação nazista e descrever minuciosamente os dramáticos eventos enfrentados, por exemplo, pelos judeus em seu país, Modiano pareceu sentir a importância de reportar os possíveis testemunhos dos que sofreram, e muito, durante os "anos sombrios". Como bem lembra Golsan, a publicação da obra Dora Bruder precedeu em poucos meses o início do julgamento de Maurice Papon, em outubro de 1997 (o romance foi lançado em abril daquele ano). Papon era acusado de crimes contra a humanidade e de ter colaborado para a deportação de judeus da França aos campos de extermínio no leste europeu. Segundo Golsan:

Para os leitores de Modiano, à luz dos processos e controvérsias de Bordeaux, há conexões surpreendentes e lúgubres. Certamente, dados fragmentados sobre as deportações de Paris e sua inclusão no texto, detalhando as trajetórias das vítimas, não são apenas ecos do depoimento de sobreviventes e das testemunhas das deportações de Bordeaux organizadas por Papon; eles amplificam o testemunho e ressaltam a extensão e o alcance da 'Solução Final' na França. ${ }^{38}$

A “amplificação" dos testemunhos parece ser mais tocante que a afirmação de que "judeus franceses foram deportados para campos de extermínio", ainda que a expressão não seja fria ou insensível, mas limitase ao âmbito do descritivo. Por mais que as análises historiográficas deste ou de outros eventos tratem de não se limitar à mera descrição e busquem explicações, questionamentos, problemas, lacunas, incongruências etc., não conseguem, efetivamente, transportar o leitor a alguma microscópica dimensão das sensações possivelmente experimentadas pelos sujeitos históricos. Mas isso seria possível de alguma forma? O historiador engendrado pelo poeta, como Golsan vê Modiano, talvez seja uma alternativa para tal. 
E se certa história, enredada por uma criação absolutamente ficcional, pudesse oferecer, em termos mais significativos (sensíveis, no caso), uma representação mais "realista" 39 e menos científica? Não se trata, todavia, de uma mera liberdade literária, artisticamente criativa, envolvendo metaforicamente ou ambientando a narrativa em um cenário histórico factualmente reconhecível. É uma história inventada que nos aproxima mais intimamente da história dos acontecimentos.

Proust, em Tempo redescoberto, ${ }^{40}$ já havia afirmado a superioridade da imaginação frente ao relato histórico. Escreveu magistralmente que "muitas vezes, no decurso da existência, a realidade me decepcionara porque, ao vislumbrá-la, minha imaginação, meu único órgão para sentir a beleza, não se lhe podia aplicar, devido à lei inevitável em virtude da qual só é possível imaginar-se o ausente". O fato é limitado, a imaginação não. Mesmo querendo-se discutir a ontologia do fato histórico, sua construção e representação, sua apropriação, distorção e perversão, haverá de se saber, de antemão, a preexistência de um fato. Esse não precisaria ser imenso como toda a Segunda Guerra Mundial, poderia ser algo "menor": de alguém (inventado e verossímil) que, por acaso, viveu na França entre 1940 e 1944. Seria impossível, contudo, passar incólume durante esse período dos grandes eventos da guerra, ainda que não estivesse propriamente implicado com o que desejavam Churchill, De Gaulle ou Eisenhower, ou se sequer se preocupasse com isso. Poderia ser um indivíduo qualquer que levava sua vida na Paris sob o controle nazista, enfrentando um dilema pessoal e nacional: ser ou não ser ambíguo...

\section{Notas}

1 MODIANO, Patrick. Uma rua de Roma. Tradução de Herbert Daniel e Cláudio Mesquita. Rio de Janeiro: Rocco, 2014c, p. 155.

2 "Je suis un produit de l'Occupation, d'une époque où pouvaient se croiser dans un même lieu un trafiquant du marché noir, un gestapiste de la rue Lauriston, et un homme traqué. C'est à cette époque que se sont rencontrés mon père, juif cosmopolite, et ma mère, d'origine flamande, comédienne dans un cinéma d'avant-guerre" [tradução nossa]. PUDLOWSKI, Gilles: Modiano le magnifique. Les Nouvelles Littéraires, $\mathrm{n}^{\circ} 2774$, de 12 a 19 de fevereiro de 1981, pp. 28-29 apud HELLÍN, Norma Ribelles. La atmósfera de la ocupación alemana en las novelas de Patrick Modiano. Çedille - Revista de estudios franceses. Espanha, n. 1, abr. 2005. Disponível em: <cedille.webs.ull.es> Acesso em: 15 ago. 2015, p. 85

3 FRANCK, Dan. Paris ocupada: os aventureiros da arte moderna (1940-1944). Tradução de Gustavo de Azambuja Feix. Porto Alegre: L\&PM, 2015, p. 31.

4 HELLÍN, op. cit., 2005, p. 83. “(...) para esquecer durante algumas horas a ocupação, o toque de recolher e as deportações dos judeus, os franceses saíam em busca de distrações, mesmo que fossem muito limitadas: visitas à família e amigos, pequenas recepções, passeios (...). O público dos teatros é numeroso, apesar da dificuldade dos horários e do transporte". 
“(...) para olvidar durante unas horas la Ocupación, el toque de queda y las deportaciones de judíos, los franceses salen en busca de distraciones, aunque éstas sean muy limitadas: visitas a la familia y amigos, pequenas recepciones, paseos (...) El público en los teatros es numeroso, a pesar de la dificultad de los horarios y los transportes" [tradução nossa]. HELLÍN, op. cit., 2005, pp. 83-84.

5 Ibid., p. 85.

6 "Raphaël Schlemilovitch, el narrador de La place de l'étoile es, a la vez y sucesivamente, judío y colaborador, proxeneta y perseguido, antisemita y amante de Eva Braun” [tradução nossa]. Ibid., p. 86.

7 Tolstói escreveu, por exemplo, “O fatalismo na história é inevitável para a explicação de fenômenos racionais (ou seja, fenômenos cuja razão não compreendemos). Quanto mais tentamos explicar racionalmente tais fenômenos, mais eles se tornam irracionais e incompreensíveis para nós" e "Se admitirmos, como fazem os historiadores, que as pessoas grandes conduzem a humanidade rumo a determinados objetivos, sejam eles a grandeza da Rússia e da França, ou o equilíbrio da Europa, ou a difusão de ideias revolucionárias, ou o progresso geral, ou o que quer que seja, então é impossível explicar os fenômenos da história sem o conceito de acaso e gênio". TOLSTÓI, Liev. Guerra e paz. v. 2 Tradução de Rubens Figueiredo. São Paulo: Cosac Naify, 2011, p. 1276 e p. 2324.

8 "Essa figura [Napoleão] permaneceu por muito tempo rodeada de intensa luz, o que contrariava certa obscuridade lendária que emana da maioria dos heróis, velando, por tempo mais ou menos longo, a verdade; mas hoje a história e a verdade andam irmanadas. Essa claridade, a história, é impiedosa". HUGO, Victor. Os miseráveis. v. 1. Tradução de Frederico Ozanam Pessoa de Barros. São Paulo: Cosac Naify, 2012, p. 456. "Waterloo, se nos colocarmos no ponto de vista culminante da questão, é intencionalmente uma vitória contrarrevolucionária (...). Querem dar-se conta do que é uma revolução? Chamem-na de Progresso. Querem dar-se conta do que é o progresso? Chamem-no de Amanhã. O amanhã constrói irresistivelmente a sua obra, começando-a hoje mesmo. Ele consegue sempre o seu objetivo (...). O século que Waterloo queria fazer parar passou-lhe por cima e continuou seu caminho. Essa vitória sinistra foi vencida pela liberdade (...). Não vejamos em Waterloo senão o que realmente existe em Waterloo. Nenhuma liberdade intencional. A contrarrevolução era involuntariamente liberal, do mesmo modo que, por um fenômeno correspondente, Napoleão era involuntariamente revolucionário. A 18 de junho de 1815, Robespierre foi apeado de seu cavalo. Ibid., pp. 505-07.

9 GINZBURG, Carlo. O fio e os rastros: verdadeiro, falso, fictício. Tradução de Rosa Freire d'Aguiar e Eduardo Brandão. São Paulo: Companhia das Letras, 2007, p. 229.

10 Ibid., pp. 178-79.

11 GOLSAN, Richard J. Modiano historien. Studies in Twentieth and Twenty-First Century Literature, Manhattan, Kansas, EUA, v. 31, n. 2, 2007. Disponível em < newprairiepress.org/ sttcl> Acesso em: 4 mai. 2015.

12 Ainda que se possa ver, nos dois casos, a colaboração francesa com os nazistas na França ocupada, sobretudo na cidade de Paris.

13 "Nunca irei saber como ela passava os dias, qual era seu esconderijo, a quem via durante os meses de inverno de sua primeira fuga, e durante as semanas da primavera, quando novamente fugiu. Aí está o seu segredo. Um simples mas precioso segredo que os algozes, os decretos, as autoridades ditas da Ocupação, a prisão, os quartéis, os campos, a História, o tempo - tudo aquilo que nos empresta e nos destrói - nunca mais lhe poderão roubar". MO- 
DIANO, Patrick. Dora Bruder. Tradução de Maria Cavalcanti Ribas Vieira. Rio de Janeiro: Rocco, 2014b, p. 137.

14 ORY, Pascal. Les collaborateurs (1940-1945). Paris: Éditions du Seuil, 1976, pp. 261262, 269-270.

15 FRANCK, op. cit., 2015, p. 96.

16 A segunda trilogia seria formada por Voyage de noces (1990), Fleurs de ruine (1991) e Dora Bruder (1997). HELLÍN, op. cit., 2005, p. 88.

17 Segundo Alan Morris, autor de uma biografia de Modiano, de 1996, até o codinome feminino indica uma dubiedade do personagem-narrador. "Um dos aspectos mais marcantes do personagem-narrador é a sua disposição em se vestir de mulher e aparentar certa feminilidade (o que se vê, por exemplo, em seu nome de guerra, Princesa de Lamballe). Tal condição implica em destruir simultaneamente, talvez não se tratando de sua sexualidade - pois afirma não ter inclinação ao travestismo -, pelo menos a divisão de gêneros: 'Ele é masculino ou feminino? '. Assim, é inevitável perguntar tal qual sobre a ambiguidade entre ser da Gestapo ou da Resistência. A resposta é ambos e nenhum. Ele não é um sujeito fácil de se definir. Ele é uma ambiguidade intrigante". "One of the most striking of these, arguably, is the narrator's willingness to dress up as woman and affect a certain femininity (echoes of which are to be found in his nom de résistance, Princesse Lamballe), for this assertive act plainly has implications that are simultaneously destructive, if not in respect of his sexuality - he claims to have no taste for transvestism - then at least in terms of his gender: 'Is he masculine or is he feminine? 'we are inevitably led to ask; but as with the question of whether he is a gestapiste or a résistant, the answer seems to be that he is both and neither. He is just not an easy man to classify, he is puzzlingly ambiguous" [tradução nossa]. MORRIS, Alan. Patrick Modiano. Oxford: Washington D.C: Berg, 1996, pp. 24-25.

18 MODIANO, Patrick. Ronda da noite. Tradução de Herbert Daniel. Rio de Janeiro: Rocco, 2014a, p. 68. Ver também MODIANO, Patrick. La ronde de nuit. Paris: Éditions Gallimard, 1969 (Collection Folio).

19 PENAUD, Guy. L'inspecteur Pierre Bonny: Le policier déchu de la "Gestapo française" du 93, rue Lauriston. Paris: Éditions l'Harmattan, 2011, pp. 9, 141, 157-224.

20 ORY, op. cit., 1976, p. 260.

21 PENAUD, op. cit., 2011, p. 157.

22 Ibid., p. 167.

23 Ibid., p. 169.

24 Ibid., pp. 220, 223, 232-233

25 MODIANO, op. cit., 2014a, p. 18.

26 Um dos líderes do grupo de resistência ao qual o personagem-narrador estava associado (ou infiltrado?).

27 Ibid., pp. 41-42.

28 "Rua de Castiglione. A coluna da praça Vendôme, que se insinua à esquerda. Praça das Pyramides. O automóvel vai cada vez mais vagarosamente, como se tivesse chegado próximo de uma fronteira. Passada a rua do Louvre, a cidade parece se abaixar subitamente. - Estamos entrando no 'ventre de Paris' - observa o Khédive. Um odor inicialmente insuportável, mas ao qual se habitua, sufoca você, mesmo que as vidraças do carro estejam fechadas. Devem ter transformado o Halles num abatedouro". Ibid., p. 45. 
29 ARENDT, Hannah. Origens do totalitarismo. Tradução de Roberto Raposo. São Paulo: Companhia das Letras, 1989, pp. 113-15.

30 PROUST, Marcel. O caminho de Guermantes. Tradução de Mario Quintana. São Paulo: Globo, 2007 (Em busca do tempo perdido, v. 3).

31 ORY, op. cit., 1976, p. 12.

32 Ibid., 1976, p. 23.

33 MODIANO, op. cit., 2014a, p. 62.

34 HELLÍN, op. cit., 2005, p. 87.

35 "Narra su historia como un sonámbulo contaría su paseo nocturno" [tradução nossa]. Ibid., p. 87.

36 Deste ponto em diante, todas as informações, interpretações e inferências correspondem ao artigo de Hellín, das páginas 87 a 92.

37 "Modiano claramente demuestra por lo tanto que prefiere el pudor a la cólera. Así, la mirada fría y distante de los personajes de Modiano denuncia la indiferencia frente a la guerra y los sufrimientos. En sus novelas, como hemos dicho, nadie se altera o se indigna. Este silencio representa el silencio de los campos de concentración. Frente a los criminales, los protagonistas pemanecen mudos. Pero la falta de denuncia constituye una denuncia de otro tipo: afirma la banalidade del mal, dejando al lector la puerta aberta a sus proprias deducciones" [tradução nossa]. Ibid., p. 90.

38 “For those who read Modiano's text in light of the proceedings and controversies in Bordeaux, there are some predictable as well as some surprising, and even eerie connections. Most obviously, Modiano's fragmentary accounts of the deportations from Paris, and his incorporation in the text of moving details concerning the victims, not only echo the testimony of survivors and witnesses of the deportations from Bordeaux Papon was accused of organizing, they in effect amplify that testimony by underscoring the extent and range of the Final Solution in France" [tradução nossa]. GOLSAN, op. cit., 2007, p. 5.

39 “Assim sendo, a literatura que se cifra a 'descrever as coisas', a fixar-lhes secamente as linhas e superfícies, é, apesar de denominar-se realista, a mais afastada da realidade, a que mais empobrece e entristece, pois corta bruscamente toda comunicação de nosso eu presente com o passado, do qual as coisas guardavam a essência, e com o futuro, onde elas nos incitam a de novo gozá-lo". PROUST, Marcel. O tempo redescoberto. Tradução de Lúcia Miguel Pereira. São Paulo: Globo, 2004 (Em busca do tempo perdido, v. 7), p. 163.

40 Ibid., p. 153

Recebido em: 03/09/2016

Aprovado em: 01/03/2018 